\title{
Research on the Innovation and Entrepreneurship Path of College Students in Ethnic Areas Based on Ideological and Political Education
}

\author{
Liu Jiong \\ Inner Mongolia University of Technology, Hohhot, Inner Mongolia, 010051
}

\begin{abstract}
With the rapid development of the times and scientific information technology, we have entered a new era digital information age under the background of the 21 century. The advent of the digital information age has promoted the occurrence of a new revolution in the world. The popularization of information technology and intelligent products has broadened the road to the future. Based on this context, our scientific information technology is developing and penetrating in a multi-disciplinary and deeper direction, which triggers a new technological and industrial revolution. Furthermore, if we want to effectively accelerate the further development of social economy and drive the supply-side structural reform in our country, we must pay attention to the cultivation of innovative and entrepreneurial talents and keep up with the pace of development of the times. Therefore, in the modern education and teaching activities, we should lay emphasis on stimulate and cultivate the innovative spirit and entrepreneurial consciousness of college students, so as to facilitate the development of innovative entrepreneurship education in colleges and universities, and help college students to carry out innovative entrepreneurial activities smoothly.
\end{abstract}

Keywords: ideological and political education; college students; innovative entrepreneurship education; path research

According to the relevant investigation in recent years, most colleges and universities only

https://doi.org/10.47852/bonviewCETR2020010213

This is an open access article published by the BON VIEW PUBLISHING PTE. under the Creative Commons Attributions License. 
focus on the teaching of innovative entrepreneurial knowledge in the quality education in colleges and universities in China, but ignore to examine the innovative entrepreneurship education of college students from the perspective of ideological and political education. If we can implement it in this way that their innovative spirit and ability can be developed at the same time, so that they can get good comprehensive quality training. In fact, ideological and political education and innovative entrepreneurship education occupy a vital position in the teaching system of higher education, and they both have a lot in common in terms of teaching content and teaching methods. If we integrate ideological and political education into the innovative entrepreneurship education of college students, it will promote the development of innovation and entrepreneurship education in the right direction. In addition, ideological and political education in colleges and universities based on innovative entrepreneurship education can also gear up the all-round development of college students. Therefore, this paper puts forward some suggestions that can encourage the integration of ideological and political education and innovative entrepreneurship education for college students, hoping to bring you some help and inspiration.

\section{The Relationship between Ideological and Political Education and College Students' Innovation and Entrepreneurship Education}

At the beginning of the article, the author has said that we are experiencing a new technological and industrial revolution under the background of the new era. At this time, we need to cultivate a large number of innovative and entrepreneurial talents. And innovative entrepreneurship education for college students can play a vital role in any field, including political, economic and educational fields. At present, most of the college students in our country think that whether they can start a business successfully entirely depends on their own luck, but not on their own comprehensive quality or the process of innovation and entrepreneurship. Their ideas clearly show that there are great loopholes in the innovative entrepreneurship education of college students. Therefore, we need to use ideological and political education in colleges and universities to achieve the goal of innovative entrepreneurship education for college students in order to effectively make up for this loophole. Through the integration of ideological and political education in colleges and universities to strengthen the ideological concept of college students so that they can correctly realize the importance of carrying out innovative entrepreneurship education and establish a correct consciousness to cultivate their ability to find, analyze and solve problems ${ }^{[1]}$. In addition to the above, it can also stimulate the entrepreneurial enthusiasm and initiative of college students, fully excavate their potential ability in this process, and make them deeply understand the difficulties and difficulties of innovation and entrepreneurship. For cultivating college students' sense of responsibility and the spirit of working hard, so that they can face the difficulties and setbacks in life with a positive attitude and achieve final success. The innovative 
entrepreneurship education of college students from the perspective of ideological and political education in colleges and universities not only gives full play to the educational and incentive functions of ideological and political education, but also concretized the contents of innovative entrepreneurship education for college students. It greatly improves the effectiveness of innovative entrepreneurship education for college students. So it can be seen that ideological and political education in colleges and universities is an important way to boost the development of innovative entrepreneurship education for college students.

\section{Problems of College Students' Innovation and Entrepreneurship Education in Ethnic Areas Based on Ideological and Political Education}

A. Not paying enough attention to the ideological and political education in college students' innovative entrepreneurship education

Under the setting of economic globalization, although our country has got some benefits from the development of it, it has also encountered some difficults at the same time. Some developed countries take advantage of the continuous development of the process of economic globalization to challenge the core values of our country and use their mainstream consciousness to infect them constantly. Under this backdrop, the ideological consciousness and cultural concept of some young people in our country have begun to waver, they not only to pursue new ideas and new cultures, but also to question the Chinese excellent traditional culture. And then they ignore the ideological and political education and teaching in colleges and universities. Even some university leaders also lack of attention to ideological and political education. Secondly, affected by the rapid development of the economic market and the pursuit of interests, some colleges and universities only focus on the promotion of short-term benefits, and do not take the ideological and political education curriculum into the ranks of improving their teaching efficiency. Even some teachers who teach ideological and political education courses are treated differently from other professional course teachers. Some ideological and political education in Colleges and universities is backward in teaching content and teaching methods, which has not been effectively solved ${ }^{[2]}$.

B. The low integration of college students' innovative entrepreneurship education and ideological and political education in colleges and universities

The author has mentioned above that ideological and political education in colleges and universities is an important way to further the development of innovative entrepreneurship education for college students. President Xi Jinping has clearly pointed out that carrying out ideological and political education activities in colleges and universities is clarifying who we want to train, how to train and for whom. But in fact, although the course of ideological and political education in China has been opened for a long time and a wide range, it has not achieved a good teaching effect. Since the 18th National 
Congress of the CPC Central Committee, innovative entrepreneurship education for college students has been a hot topic in society. But our country started a little later than other developed countries, so the level of innovative entrepreneurship education for college students is still in a low stage. This affects the integration of innovative entrepreneurship education and ideological and political education in colleges and universities ${ }^{[3]}$.

\section{Research on the Path of Innovative Entrepreneurship Education for College Students in Ethnic Areas Based on Ideological and Political Education}

A. To promote the cognition of ideological and political education in college students' innovative entrepreneurship education

Under the background of the new technology and industry reform, college students are facing the severe employment situation. In order to solve the employment difficulties of college students and improve the employment rate of them, most colleges and universities generally present a kind of teaching phenomenon of "emphasizing practice and neglecting theory" in the process of daily education and teaching. Although this teaching method can harvest certain teaching benefits in a short time, it is contrary to core values and scientific outlook on development of our country. If colleges and universities want to improve their employment rate well, they must integrate ideological and political education in college students' innovative entrepreneurship education, and also pay enough attention to ideological and political education. It can fully realize the great role of ideological and political education in innovative entrepreneurship education, such as normative guidance and transformation. And if we can integrate the innovative entrepreneurship education into the ideological and political education of colleges and universities, we can not only cultivate the noble moral sentiment and good spiritual quality of college students, but also help them to clear their own development direction. In this way, it can develop toward the right direction in the process of innovation and entrepreneurship. On this basis, normal colleges and universities must pay attention to the application and penetration of ideological and political education, in order to correct the wrong consciousness of college students, and make them actively realize the importance of innovation and entrepreneurship education. Confucius once said that by using government orders to govern the people and to restrict the people by punishment, people can temporarily avoid sin, but they will not be ashamed of not abiding by the rules. If the people are ruled by morality and restrained by etiquette, they will not only have a sense of shame, but also correct their mistakes. Innovation and entrepreneurship education is the same. The infiltration of ideological and political education in colleges and universities is to regulate students' words and deeds, so that they can well comply with the relevant rules of the economic market and the relevant laws and regulations of the state $^{[4]}$.

B. Scientifically setting up ideological and political education curriculum to promote the deep 
integration of innovation and entrepreneurship education

First of all, ideological and political education in colleges and universities can provide certain theoretical guidance for innovative entrepreneurship education of college students. To a certain extent, it promotes the expansion of theoretical research on college students' innovative entrepreneurship education. Secondly, as an important carrier of ideological and political education in colleges and universities, innovative entrepreneurship education can enrich the teaching connotation of ideological and political education. In some degree, it boosts the innovation and development of ideological and political education in colleges and universities, so that the ideological and political education can be better combined with the innovative entrepreneurship education of college students. In addition, through the infiltration and integration of ideological and political education in colleges and universities, not only can effectively facilitate the overall development of college students in the process of innovative entrepreneurship education, but also can give full play to the contribution that college students can make to society and the country. Therefore, colleges and universities should actively integrate the resources of ideological and political education and innovative entrepreneurship education in the actual teaching process, so as to allow full play to the teaching value of ideological and political education and make their own talents meet the needs of modern society, improving the employment rate ${ }^{[5]}$.

C. Strengthen the orientation of innovation and entrepreneurship education and combine education with technology

The innovative entrepreneurship education based on ideological and political education in colleges and universities should not only attach importance to the teaching of relevant skills, but also pay attention to the cultivation of college students' comprehensive quality and good moral character. Only in this way can we meet the fundamental goal of education and teaching in our country. According to the relevant investigation reality, the innovation and entrepreneurship education courses offered by universities in the past were relatively single, and the daily teaching only focused on the selection of professional students for practical training. Under the context of modern teaching, this teaching method not only meets the development needs of the times and society, but also meets the innovative and entrepreneurial needs of college students in the fierce market competition. Therefore, for effectively improving the innovative and entrepreneurial skills of college students, colleges and universities must innovate and optimize their own innovative entrepreneurial teaching means and models. It is also necessary to strengthen practical teaching and establish the correct educational idea of practice and theory. With the rapid development of science and technology, teachers should pay attention to the use of information technology and Internet, seize the development opportunities of the Internet era in order to promote the birth of Internet Plus innovation and entrepreneurship teaching mode, and optimize their own education and teaching ${ }^{[6]}$. 


\section{Conclusion}

In a word, the integration and penetration of innovative entrepreneurship education and ideological and political education in colleges and universities has very positive practical significance. It can not only give full play to the educational role of ideological and political education, but also greatly enhance the long-term development of innovative entrepreneurship education in colleges and universities. So that it can cultivate more excellent high-quality, high-level innovative entrepreneurial talents for the country and society.

\section{Acknowledgement}

This work is supported in part by Scientific research projects of colleges and universities in Inner Mongolia Autonomous Region "Construction of Educational Model of Science and Technology Innovation in Engineering Colleges in Ethnic Areas"(NJSZ1917)

\section{References}

[1] Zhao Ning. A Study on the Development Strategy of College Students'Innovative Entrepreneurship Education from the Perspective of Ideological and Political Education [J].].1 Research and practice of innovative Entrepreneurship Theory ,2020,3(1):86-87.

[2] Wang Yuxiang. A Study on Ideological and Political Education Based on College Students' Innovative Entrepreneurship Education [J].].1 Research and practice of innovative Entrepreneurship Theory ,2019,(8):137-138.

[3] Li Chunlan. A Study on the Ideological and Political Education of College Students from the Perspective of J]. and Entrepreneurship Health Vocational Education ,2018,36(15):3-4.

[4] Weng Hao. A Way to Integrate Ideological and Political Education into College Students'Innovation and Entrepreneurship Education [J].].1 Research on ideological and political Education 36(1):152-155.

[5] Fan Peipei. A Study on Ideological and Political Education and Cultivation of College Students' Innovative Entrepreneurship Quality [J].] and Management Watch ,2018,(1):141-142.

[6] Zhang Haiqing. A Study on Ideological and Political Guidance in Innovation and Entrepreneurship Education in Colleges and Universities in Minority Areas [J]. Journal of Inner Mongolia University of Finance and Economics, v.16;No.83(3):84-87.,2018 